ABDI: Jurnal Pengabdian dan Pemberdayaan Masyarakat ISSN: 2656-369X (Print), 2684-8570 (Online)

Volume 1 No. 2, Desember 2019

http://abdi.ppj.unp.ac.id/index.php/abdi

Email: abdi@ppj.unp.ac.id

DOI: https://doi.org/10.24036/abdi.vli2.11

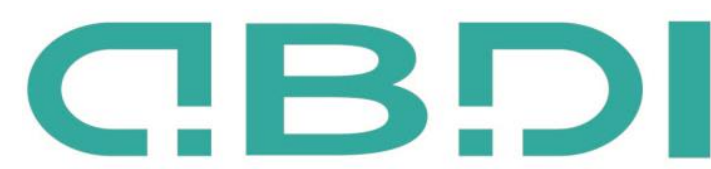

ABDI: JURNAL PENGABDIAN DAN PEMBERDAYAAN MASYARAKAT

\title{
Pelatihan Teknik Pengumpulan Data Geografis Berbantuan Peta dan Citra Pada Siswa SMA
}

\author{
Febriani Safitri ${ }^{1}$, Alfasis Romarak Ap ${ }^{2}$, Renny Thereesje Tumober ${ }^{3}$ \\ 1,2,3 Jurusan Pendidikan IPS Universitas Cenderawasih
}

Email: geofebrhy@gmail.com, araprom47@gmail.com, rennytumober2204@gmail.com

\begin{abstract}
Abstrak
Pembelajaran penelitian-penelitian geografi merupakan salah satu goal pendidikan dalam Kurikulum 2013. Kompetensi yang harus dicapai siswa dalam materi ini adalah memahami langkah-langkah penelitian geografi, termasuk teknik-teknik pengumpulan data geografis. Karena itu, diperlukan pelatihan bagi siswa yang bertujuan untuk meningkatkan kemampuan siswa dalam memahami teknik pengumpulan data geografis. Kegiatan pelatihan menggunakan media peta dan citra. Luaran utama yang diharapkan dalam pengabdian ini adalah jurnal atau publikasi ilmiah. Mitra kegiatan pengabdian ini adalah siswa SMA YPK Diaspora Kotaraja dengan lokasi kegiatan di sekolah dan Kawasan Pantai Base-G, Kota Jayapura. Metode pelaksanaan kegiatan pengabdian dalam bentuk pelatihan. Kegiatan pelatihan dilaksanakan dalam bentuk pemberian materi, praktek interpretasi peta dan citra. Hasil kegiatan pengabdian menunjukkan bahwa siswa peserta pelatihan telah mampu mengumpulkan data geografis melalui interpretasi peta dan citra.
\end{abstract}

Kata Kunci: Citra, Peta, Teknik pengumpulan data

\section{Abstract}

Learning geography research is one of the educational goals in the 2013 curriculum. The competency that students must achieve in this material is to understand the steps in geography research, including geographic data collection techniques. Therefore, the training is needed for students who aim to improve students' abilities in understanding geographic data collection techniques. The training is using map and image media. The main outcome expected in this service is a journal or scientific publication. The partners of this community service activity are the students of YPK Diaspora Kotaraja high school and the location of activities in the school and the Base-G Beach Area, Jayapura City. The methods are lecture, $Q$ and A, discussions dan field practices. The results show that the students had been able to collect geographical data through map and image interpretation. Keywords: Data collection techniques, Imagery, Map

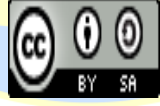




\section{Pendahuluan}

Pembelajaran dengan pendekatan saintifik (scientific approach) merupakan salah satu implementasi Kurikulum 2013. Proses pembelajaran dalam pendekatan saintifik ini dirancang agar peserta didik mendapatkan pengalaman belajar melalui kegiatan pengamatan, pertanyaan atau hipotesis, pengumpulkan data, pengujian, analisis, dan perumusan hasil pengamatan yang dilakukan. (1) Salah satu implementasi pendekatan saintifik dalam pembelajaran geografi di SMA adalah dimasukkannya materi penelitian-penelitian atau riset geografi. Materi penelitian-penelitian geografi dalam kurikulum 2013 matapelajaran geografi diberikan pada kelas X semester I. (2) Bentuk implementasi lainnya adalah penguasaan teknologi informasi geografi, seperti peta, sistem informasi geografi dan penginderaan jauh. Tren-tren penelitian geografi saat ini mengikuti perkembangan teknologi informasi geografi.

SMA YPK Diaspora Kotaraja merupakan salah satu SMA swasta yang bernaung pada lembaga pendidikan Yayasan Pendidikan Kristen (YPK), Gereja Kristen Injil (GKI) di Tanah Papua dan baru dua tahun terakhir ini menggunakan Kurikulum 2013 (K-13). Kendala utama dalam penerapan implementasi K-13 adalah keterbatasan sarana dan prasarana serta kemampuan guru dalam pemanfaatan informasi teknologi (IT). Penguasaan IT tentu sangat dibutuhkan dalam pembelajaran geografi, khususnya pada materi-materi pemetaan, sistem informasi geografi (SIG), dan penginderaan jauh (remote sensing).

Pembelajaran materi penelitian-penelitian geografi membutuhkan pengetahuan geografi yang kompleks dan komprehenship sedangkan materi ini diberikan di semester awal pembelajaran geografi di SMA. Beberapa permasalahan yang dihadapi oleh guru geografi di SMA YPK Diaspora dalam membelajarkan materi penelitian-penelitian geografi adalah sebagai berikut: 1) pengetahuan dasar geografi siswa masih rendah sedangkan materi ini memerlukan pengetahuan geografi yang kompleks, 2) keterbatasan pemahaman guru terkait teknik pengumpulan data geografis, 3) penguasaan teknologi informasi geografis, baik guru maupun siswa yang masih terbatas, dan 4) pembelajaran geografi di sekolah hanya sebatas penyampaian konsep dan teori. Karena itu, pihak sekolah, Kepala SMA YPK Dispora Kotaraja meminta kepada tim pengabdi Universitas Cenderawasih untuk memberikan pengetahuan tambahan kepada siswa SMA YPK Diaspora Kotaraja terkait teknik pengumpulan data geografis, baik data fisik maupun data sosial.

Berdasarkan permasalahan tersebut, tim pengabdian masyarakat Universitas Cenderawasih menetapkan suatu bentuk pengabdian dengan melatih siswa SMA YPK Diaspora Kotaraja dalam pengumpulan data geografis. Mengikuti tren penelitian saat ini, maka pelatihan teknik pengumpulan data menggunakan peta dan citra. Karena itu, harapan dari kegiatan pelatihan ini selain meningkatkan pengetahuan teknik pengumpulan data, juga menambah keterampilan penggunaan peta dan citra pada siswa.

\section{Metode Pelaksanaan}

Kegiatan pengabdian kepada masyarakat dilaksanakan di SMA YPK Diaspora Kotaraja yang berlokasi di Distrik Abepura, Kota Jayapura. Kegiatan pengabdian kepada masyarakat ini merupakan permintaan dari guru geografi SMA YPK Diaspora Kotaraja. Melalui kepala sekolah, tim pengabdi melakukan sosialisasi kegiatan kepada mitra sasaran, yaitu siswa SMA YPK Diaspora Kotaraja. Pihak mitra memiliki kemampuan dan kemauan untuk mendapatkan pelatihan dan menyiapkan ruangan yang memadai yang mendukung kegiatan pengabdian.

Bentuk kegiatan pengabdian kepada masyarakat berupa pelatihan teknik pengumpulan data berbantuan peta dan citra. Siswa dibimbing untuk menerapkan hasil pelatihan dalam rangka meningkatkan kemampuan siswa dalam mengumpulkan data geografis. Tahapan pelatihan meliputi: 1) penjelasan materi terkait teknik pengumpulan data geografis, interpretasi peta dan interpretasi citra, 2) pelatihan interpretasi peta yang menitikberatkan pada pemahaman terhadap komponen-komponen peta, 3) pelatihan interpretasi citra yang menitikberatkan pada kemampuan interpretasi citra secara visual untuk mendapatkan informasi dari citra.

Bahan dan alat yang digunakan dalam kegiatan pelatihan meliputi: 1) slide materi, 2) bahan dan alat untuk interpretasi peta dan citra yang meliputi peta tematik, citra satelit google earth, kertas kalkir, tabel interpretasi, pulpen, pensil, spidol OHP berwarna, dan penggaris. 
Untuk mengetahui keberhasilan kegiatan pengabdian ini, maka tim pengabdi Universitas Cenderawasih melakukan evaluasi untuk mengetahui perubahan pengetahuan siswa sebelum dan setelah diberikan pelatihan maka tim pengabdi melakukan pendampingan untuk memantau pelaksanaan kegiatan dan mengoreksi hasil karya, hasil interpretasi peta dan citra selama pelatihan di sekolah maupun di lapangan. Komponen-komponen yang diobservasi sebagai berikut:

1. Kemampuan interpretasi peta, dimana siswa dapat:

a. Mengetahui informasi yang disampaikan peta melalui judul peta

b. Membaca dan membedakan informasi berdasarkan simbol-simbol peta

2. Kemampuan interpretasi citra, dimana siswa dapat:

a. Mengidentifikasi objek berdasarkan unsur-unsur interpretasi citra

b. Mengenali dan melakukan crosscheck objek yang telah diinterpretasi dengan objek di lapangan

3. Kemampuan membuat peta dari hasil interpretasi citra

Kemampuan interpretasi peta dan citra dapat diketahui melalui observasi secara langsung selama proses kegiatan pelatihan serta dari peta yang telah dibuat.

\section{Hasil dan Pembahasan}

\section{Hasil Kegiatan}

Interpretasi peta dan interpretasi citra adalah teknik pengumpulan data untuk penelitian wilayah.

(3) baik untuk data fisik maupun data sosial. Kegiatan pelatihan teknik pengumpulan data geografis berbantuan peta dan citra diharapkan memberikan perubahan positif terhadap pemahaman dan pengetahuan peserta atau siswa terkait teknik pengumpulan data khususnya melalui interpretasi peta dan citra. Perubahan pengetahuan siswa setelah diberikan pelatihan adalah sebagai berikut.

1. Kemampuan interpretási peta

Jika sebelum pelatihan siswa tidak dapat menyebutkan informasi yang disajikan pada peta tematik. Setelah pelatihan interpretasi peta, siswa dapat menyampaikan informasi yang disajikan peta tematik dengan membaca judul pada peta. Siswa juga memahami komponen-komponen peta yang lain, seperti skala, legenda, orientasi peta, koordinat, garis astronomis, simbol, inset, dan sumber serta informasi pembuat peta. Siswa pun dapat membaca dan membedakan informasi yang disajikan berdasarkan simbol-simbol peta. Kegiatan interpretasi peta dalam pelatihan ini menggunakan beberapa peta tematik Kabupaten Jayapura, meliputi Peta Geologi, Peta Geomorfologi, Peta Penggunaan Lahan, Peta Kemiringan Lereng, Peta DAS, dan Peta Jenis Tanah.

2. Kemampuan interpretasi citra

Pemahaman siswa terkait citra sebelum pelatihan sangat minim, dimana siswa tidak dapat membedakan citra foto udara dan citra satelit. Unsur-unsur interpretasi citra pun belum dipahami sehingga tidak dapat membedakan kenampakan objek yang disajikan pada citra. Dalam kegiatan pelatihan ini, interpretasi citra menggunakan citra satelit google earth untuk mengidentifikasi kenampakan tutupan lahan atau penggunaan lahan pada dua citra satelit Kawasan Pantai Base-G, Kota Jayapura dengan perekaman yang berbeda, yaitu tahun 2006 dan 2019. Setelah pelatihan, siswa dapat mengidentifikasi kenampakan objek berdasarkan unsur-unsur interpretasi citra. Unsurunsur interpretasi citra meliputi rona, warna, bentuk, ukuran, tekstur, pola, bayangan, situs, asosiasi, dan konvergensi bukti. (4) . Untuk memastikan kebenaran hasil interpretasi, siswa diajarkan cara mencocokkan (crosscheck) hasil interpretasi dengan kondisi nyata di lapangan.

3. Kemampuan membuat peta dari hasil interpretasi citra

Hasil interpretasi citra diperoleh data-data berupa kenampakan objek tutupan dan penggunaan lahan Kawasan Pantai Base-G tahun 2006 dan 2019. Untuk mendapatkan data perubahan penggunaan lahan, maka dibuat peta penggunaan dari kedua citra tersebut, kemudian melakukan overlay untuk melihat perubahan penggunaan lahannya. Siswa dilatih membuat peta dari hasil interpretasi citra dan melengkapi keterangan-keterangan peta sesuai dengan kaidah pemetaan. Hasil yang diperoleh bahwa para siswa peserta pelatihan telah mampu membuat peta penggunaan lahan berdasarkan hasil interpretasi citra pada kegiatan sebelumnya, mendeleniasi batas-batas kenampakan masing-masing objek penggunaan lahan, dan menghitung perubahan penggunaan lahan di Kawasan Pantai Base-G tahun 2006 dan 2019. 
Hasil pelatihan menunjukkan bahwa siswa telah mampu melakukan mengambil data geografis melalui interpretasi peta dan citra. Siswa dapat memperoleh data geologi, jenis tanah, kemiringan lereng, DAS, penggunaan lahan dan geomorfologi Kabupaten Jayapura melalui interpretasi peta, sedangkan melalui interpretasi citra dan pembuatan peta, siswa memperoleh data perubahan penggunaan lahan Kawasan Pantai Base-G, tahun 2006 dan 2019 dalam bentuk peta.

\section{Pembahasan}

Kegiatan pengabdian kepada masyarakat dilaksanakan di SMA YPK Diaspora Kotaraja. Kegiatan dimulai dengan melakukan survei lapangan untuk tahap penyusunan rencana kerja. Kegiatan survei dilakukan untuk mengidentifikasi permasalahan yang ada di SMA YPK Diaspora Kotaraja. Tim pengabdi Universitas Cenderawasih kemudian mencari solusi untuk pemecahan masalah tersebut melalui kegiatan pengabdian kepada masyarakat. Kegiatan survei menghasilkan hasil diskusi antara dosen dengan kepala sekolah dan guru geografi SMA YPK Diaspora Kotaraja yaitu pelatihan teknik pengumpulan data geografis berbantuan peta dan citra untuk menambah pengetahuan dan keterampilan teknik pengumpulan data serta penggunaan peta dan citra pada siswa. Kegiatan pelatihan ini dapat dikatakan berhasil jika sesuai dengan tujuan yang ingin dicapai serta bahan yang akan digunakan dalam kegiatan tersajikan dan terencana dengan baik. Karena itu, salah satu persiapan tim pengabdi sebelum pelaksanaan kegiatan adalah menyusun materi pelatihan secara terstruktur, logis, dan berkesinambungan, meliputi materi tentang: 1) konsep dasar data geografis, 2) teknik pengumpulan data geografis, dan 3) interpretasi peta dan citra.

Pelaksanaan kegiatan pengabdian kepada masyarakat dilaksanakan oleh tim pengabdi yang terdiri dari 3 dosen dari Program Studi Pendidikan Geografi dan dibantu oleh 2 mahasiswa Pendidikan Geografi sebagai tenaga pendamping (Gambar 1). Kegiatan pelatihan dilaksanakan selama dua hari, yaitu hari Jumat - Sabtu, tanggal 28 - 29 Juli 2019 dengan beberapa tahapan kegiatan, yaitu 1) pemberian materi terkait teknik pengumpulan data geografis, 2) praktek intepretasi peta dan citra secara visual, 3) kegiatan lapangan atau crosscheck hasil interpretasi. Total peserta yang mengikuti kegiatan pelatihan ini sebanyak 52 siswa.

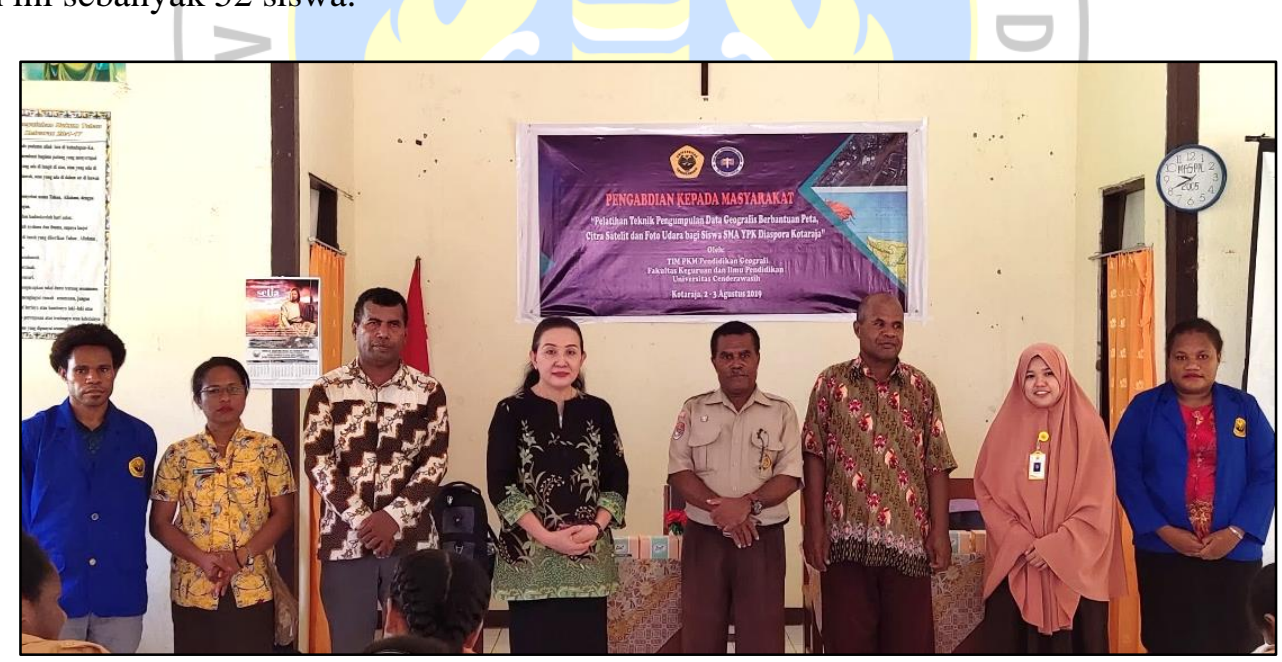

Gambar 1. Tim Pelaksana Kegiatan Pengabdian kepada Masyarakat Universitas Cenderawasih (Sumber: dokumentasi kegiatan, Juli 2019)

\section{Kegiatan Hari Pertama}

Kegiatan pengabdian hari pertama adalah pemberian materi tentang konsep dasar data geografis, teknik pengumpulan data geografis, dan interpretasi peta dan citra. Kegiatan ini dilanjutkan dengan praktek interpretasi peta dan interpretasi citra oleh siswa dan didampingi oleh tim pengabdi. Peserta dilatih untuk memahami komponen-komponen dalam pembuatan peta dan mengidentifikasi gejala atau objek serta informasi yang dapat diperoleh dari peta. untuk interpretasi citra, peserta dilatih untuk menginterpretasi citra berdasarkan 9 unsur interpretasi citra. Dalam kegiatan pengabdian ini, siswa dilatih untuk membuat peta dari hasil interpretasi citra. Peta yang digunakan dalam latihan 
interpretasi peta adalah peta-peta tematik Kabupaten Jayapura sedangkan untuk interpretasi citra, digunakan citra google earth Kawasan Pantai Base-G, Kota Jayapura skala 1:100 meter, perekaman tahun 2006 dan 2019. Data yang diperoleh dalam pelatihan interpretasi citra adalah data tutupan atau penggunaan lahan Kawasan Pantai Base-G tahun 2006 dan 2019 dan perubahan tutupan lahannya.

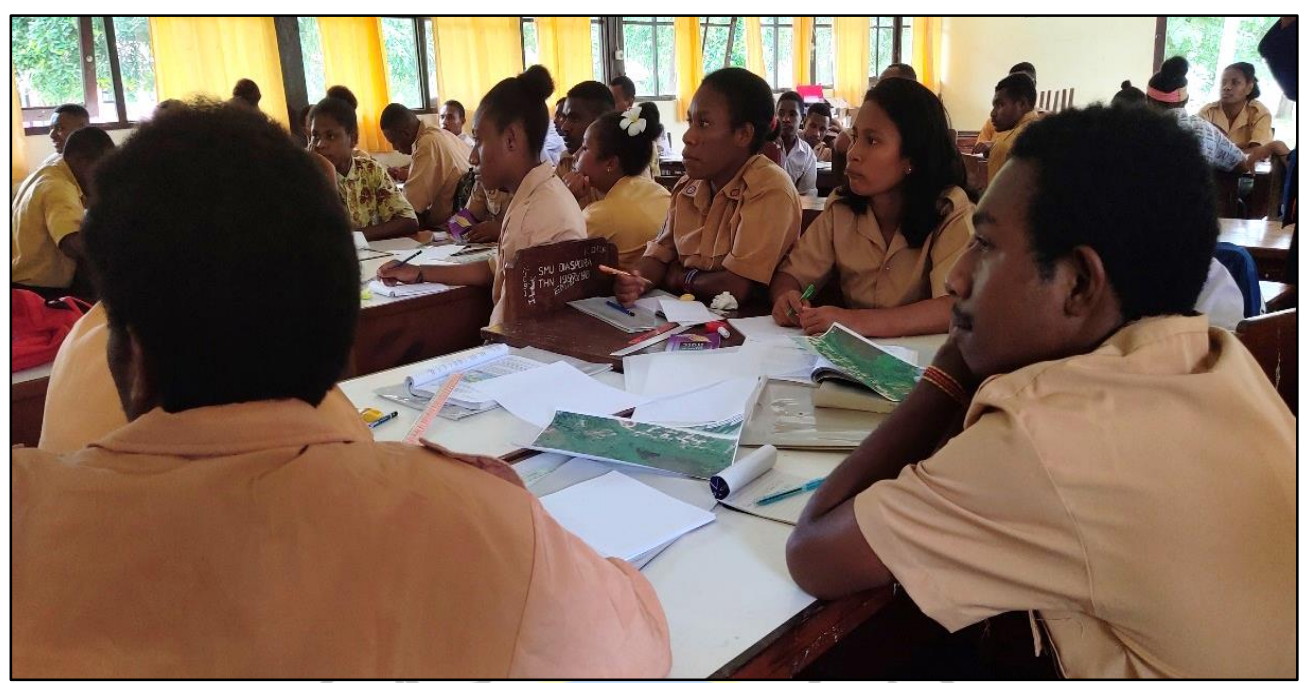

Gambar 2. Peserta menerima materi pada kegiatan pegabdian hari pertama (Sumber: dokumentasi kegiatan, Juli 2019)

\section{Kegiatan Hari Kedua}

Kegiatan pengabdian hari kedua adalah kegiatan lapangan untuk memastikan kebenaran hasil interpretasi citra dan peta yang dibuat pada pelatihan hari pertama. Kegiatan lapangan dilaksanakan di Kawasan Pantai Base-G, Kota Jayapura. Kegiatan ini dimulai dengan mempersiapkan peta penggunaan lahan yang telah dibuat. Peta yang digunakan adalah peta penggunaan lahan tahun 2019. Tim pengabdi memberikan penjelasan singkat terkait kegiatan. Selanjutnya, siswa mencocokkan peta yang telah dibuat dengan kenyataan objek di lapangan. Siswa memberikan keterangan pada objek pada peta dan memperbaiki interpretasi objek yang keliru. Kegiatan lapangan diakhiri dengan crosscheck hasil pengambilan data, tanya-jawab dan makan siang bersama.

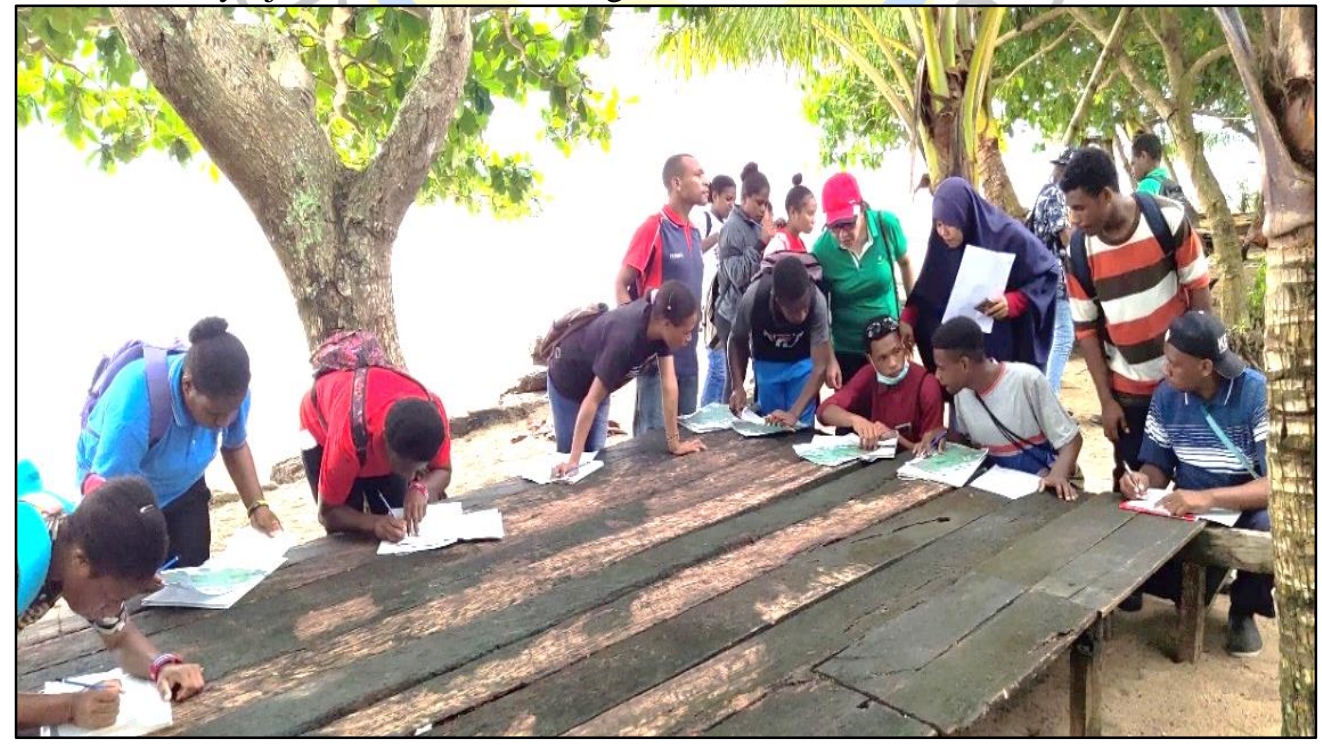

Gambar 3. Siswa melakukan cross check peta penggunaan lahan di lokasi yang dipetakan (Sumber: Dokumen Kegiatan, Juli 2019) 
Kegiatan pengabdian ditutup oleh Kepala SMA YPK Diaspora Kotaraja dengan menyampaikan terima kasih atas pelaksanaan kegiatan pengabdian kepada masyarakat ini dan meminta kesediaan waktu kepada tim pengabdi Universitas Cenderawasih untuk melakukan kegiatan pengabdian diwaktu mendatang karena kegiatan ini selain memberikan pengetahuan tambahan kepada siswa, juga memberi nilai tambah dalam peningkatan kualitas sekolah.

\section{Kesimpulan}

Kegiatan pengabdian kepada masyarakat, pelatihan teknik pengumpulan data geografis berbantuan peta dan citra mendapatkan respon yang positif dari pihak SMA YPK Diaspora Kotaraja. Kegiatan pengabdian telah berlangsung dengan baik dan memberikan tambahan pengetahuan kepada siswa, terutama dalam teknik pengumpulan data melalui peta dan citra. Siswa yang sebelumnya mengenal peta dan citra sebatas konsep saja, sekarang telah mampu mengambil data melalui interpretasi peta dan citra. Kegiatan pengabdian seperti ini dapat dilakukan secara rutin di lokasi yang sama maupun di lokasi yang berbeda dengan sasaran siswa/siswi yang benar-benar membutuhkan pengetahuan tentang geografi, khususnya dalam materi penelitian-penelitian geografi.

\section{Daftar Pustaka}

Susilana R, Ihsan H. (2014). Pendekatan Saintifik dalam Implementasi Kurikulum 2013 berdasarkan Kajian Teori Psikologi Belajar. Jurnal Edutech, 2(1).

Nofrion. (2015). Penguatan Kurikulum dan Pembelajaran Geografi. Seminar Nasional Fakultas Ilmu Sosial Universitas Negeri Malang.

Yunus H.S. (2010). Metodologi Penelitian Wilayah Kontemporer. Yogyakarta: Pustaka Pelajar.

Somantri L. (2009). Teknologi Penginderaan Jauh (remote sensing). Kegiatan Kunjungan Siswa dan Guru MAN Cibalong ke Laboratorium Jurusan Pendidikan Geografi. UPI

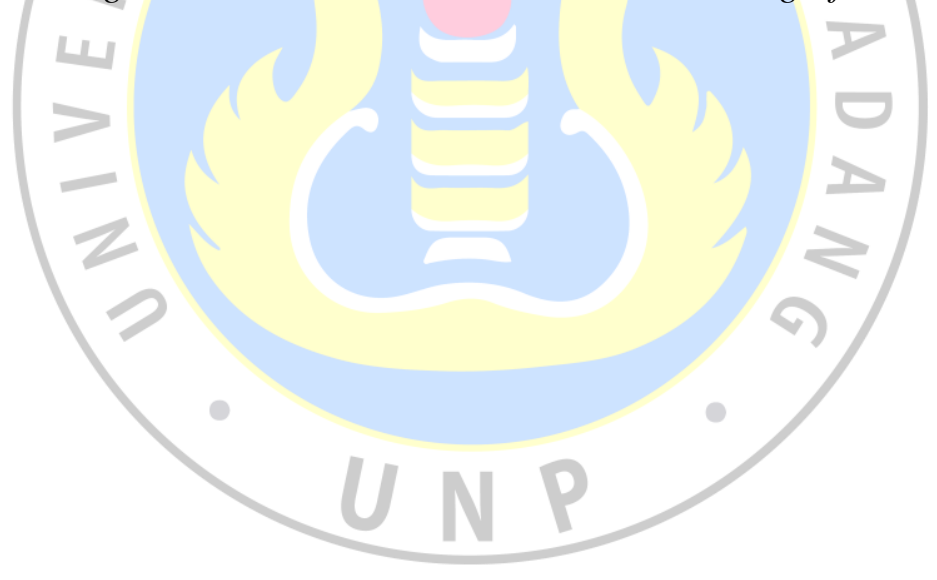

